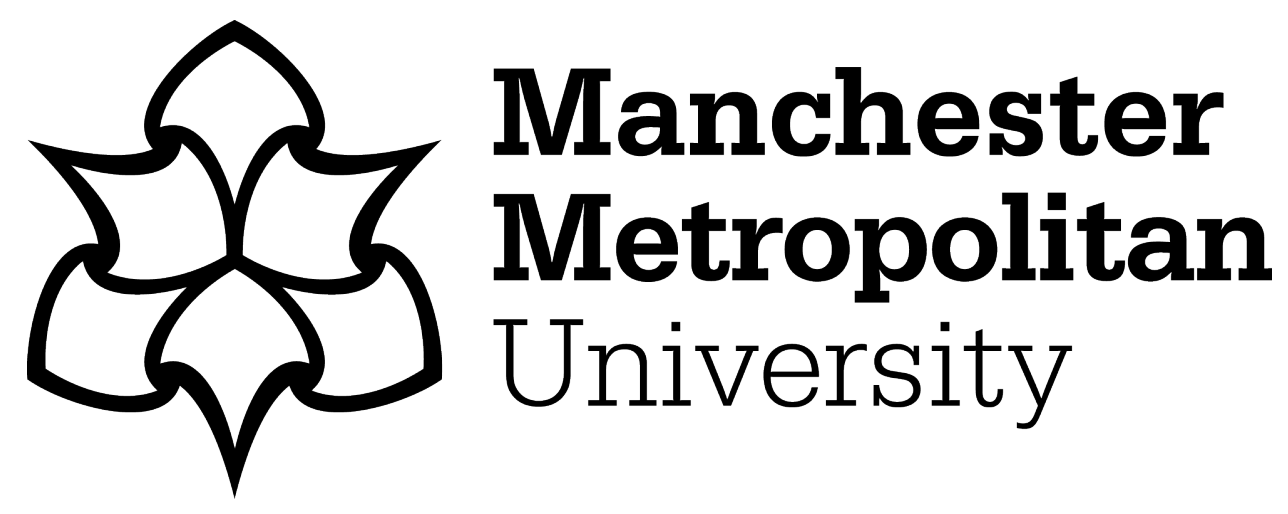

Rousell, David ORCID logoORCID: https://orcid.org/0000-0002-4509-6128 (2019) Inhuman forms of life: on art as a problem for post-qualitative research. International Journal of Qualitative Studies in Education, 32 (7). pp. 887-908. ISSN 0951-8398

Downloaded from: https://e-space.mmu.ac.uk/622585/

Version: Accepted Version

Publisher: Taylor \& Francis (Routledge)

DOI: https://doi.org/10.1080/09518398.2019.1609123

Please cite the published version 


\title{
Inhuman Forms of Life: On art as a problem for post-qualitative research
}

\author{
David Rousell, Manchester Metropolitan University
}

\section{Accepted for: International Journal of Qualitative Studies in Education}

\begin{abstract}
Researchers navigating the ontological turn in educational research have increasingly looked to art as an alternative to conventional modes of qualitative inquiry. However, the rapprochement between art and post-qualitative research remains problematic. While some see this turn coinciding with established genealogies in arts-based research, others suggest that existing models of arts-based inquiry are largely incompatible with the radical onto-epistemological orientations associated with post-qualitative research. This paper argues that the integration of art into the social sciences is far from settled, while also offering a series of speculative propositions for an inhuman aesthetics that is responsive to the ontological turn. This inhuman theory of art is elaborated through Deleuze and Guattari's philosophy, and extended through an analysis of collaborative artworks produced by undergraduate visual art students. This leads to a consideration of how post-qualitative approaches might enable mutual activations between art, philosophy, and social research.
\end{abstract}

Keywords: art; aesthetics; post-qualitative research; Deleuze and Guattari; collaboration

\section{Introduction: The Problem of Art}

As the ontological turn in the social sciences picks up steam, researchers are increasingly turning to post-qualitative research as an alternative to conventional models of qualitative inquiry in education. St. Pierre $(2011 ; 2013 ; 2016)$ has proposed post-qualitative research as a mode of inquiry that takes a philosophy of immanence as its point of departure, and in doing so, rejects the entire apparatus of qualitative research methodology, and indeed, the very concept of methodology itself. Because a philosophy of immanence places life, thought, being, 
and nature on a single surface of existence, there can be no predetermined research methods, practices, or categories in post-qualitative research (St. Pierre, 2013). Despite St Pierre's argument that post-qualitative research is fundamentally anti-paradigmatic and antimethodological, "post-qualitative" is increasingly used as a subsuming term to name a new methodological paradigm in the social sciences (see, for instance, Demuth, 2015; Heimans, 2016; Johanssen, 2016; Kuby, Aguayo, \& Holloway, 2016; Wolfe, 2017). What is often claimed to be "post-qualitative" about these approaches is their engagement with ontological, Deleuzian, and/or new materialist turns across a wide array of disciplines, including political ecology (Bennett, 2010; Protevi, 2013), feminist science and technology studies (Barad, 2007; Wilson, 2015), education (Snaza \& Weaver, 2015), the arts (Bolt, 2013; Manning \& Massumi, 2014), and the posthumanities (Braidotti, 2013; Grosz, 2017; Morton, 2013; Weinstein \& Colebrook, 2016). In resisting the bifurcation of nature|culture, subject|object, human|nonhuman and theory|practice into binary categories, these emerging approaches support experimentation with relational ways of thinking and doing social research that demand varying revisions of conventional qualitative methods, ranging from deconstruction, to reimagining, to the outright rejection of qualitative methodology and its associated concepts (St. Pierre, 2016). As a result, we are now seeing the rapid proliferation of "a thousand tiny methodologies" that, to varying degrees, attempt to elude the standards, codes, and criteria of traditional qualitative methods in education and the social sciences more broadly (Lather, 2013, p. 635).

In the recent proliferation of approaches named as post-qualitative, art has been posed as a possible solution to the mismatch between new materialist onto-epistemologies and conventional qualitative research methods such as interviews and participant observation (Guyotte, 2017; Holbrook \& Fourchier, 2014; Pacini-Ketchabaw, Kind, \& Kocher, 2016). Some scholars see post-qualitative research coinciding with established genealogies of practice 
in art-based research (Boulten-Funke, 2014; Sinner, 2017), or suggest that arts-based research is already a form of post-qualitative research (Hernandez, Gil, \& Coscollola, 2018). Others argue that existing models of arts-based research are largely incompatible with the radical ontoepistemological orientations associated with post-qualitative research, and the ontological turn more broadly (jagadzinski \& Wallin, 2012; Rousell, 2017; Rousell, Lasczik, Irwin, \& Cook, 2018).

While arts-based research offers a creative alternative to research approaches predicated on human language and voice, it retains a historical preoccupation with positioning art as a humanising knowledge practice that serves to represent the interior, personal experience of the liberal subject. This can be broadly described as a "hylomorphic" understanding of art as the human imposition of idealised form onto passive matter, such that the work of art becomes emblematic of human exceptionality, superiority, and mastery over nature (Rousell $\&$ Fell, 2018). Artworks are commonly accorded status as representations of an artist's personal experiences, beliefs, intentions, and skills that imbue the material world with meaning, representations that are subsequently evaluated by the viewer, audience or spectator as rarefied forms of cultural knowledge. Such approaches delimit artistic practice as an operation "that moulds matter into forms according to an ideal model, an operation by which the world appears as obedient and predictable representations" (Zepke, 2005, p. 3). As enclosed within the hylomorphic schema, conventional modes of arts-based research have sought to legitimise art as a method within the normative paradigm of humanist, qualitative research methodology, an objective which stands in stark contrast to the immanentist, new materialist and antimethodological orientations of post-qualitative inquiry.

Rather than posing art as a hylomorphic solution to the "crisis" of qualitative methodology, this article attempts to recoup art as a problem, a provocation, and an irritant for the humanities and social sciences. It suggests that the ontological turn is not necessarily a call 
to art, nor simply an affirmation of what artists and arts-based researchers have been doing all along. The article argues instead for a more robust engagement with aesthetics and the ontology of art, with a focus on the particular potentials of art as a relational mode of production and experimentation that is distinct from philosophy and social science. Indeed, one of the dangers of a rapprochement between art and post-qualitative research is that it potentially leads to blended and diluted hybridisations that are not quite art, not quite philosophy, and not quite social science. In refusing to accept a simple resolution or settlement between art and postqualitative research, the paper offers a series of speculative propositions for an inhuman theory of art that generates new forms of life through creative modes of experimentation. Drawing on theories of art proposed by Deleuze and Guattari (1987; 1994), Massumi (2011; 2015), and Grosz (2008), this involves a rethinking of art in terms of differential forces and intensities of composition, expression, and sensation that activate inhuman tendencies and capacities for experience.

The notion of the "inhuman" is developed over the course of the article in order to conceptualise that which precedes, exceeds, proceeds, and importantly, includes human life as one of innumerable elements, forces, and modes of existence. By gesturing towards the immanent totality of life and its capacity for producing difference, the concept of the inhuman evokes "the terrain within which the figure of the human (and its posthuman others, which would include animals, bacteria, viruses, plants, technology, and virtuality) takes place" (Weinstein \& Colebrook, 2016, p. 60). Where the more commonly used terms "nonhuman" and "more than human" tend to refer outside of or beyond the human, "inhuman" includes the figure of the human as but one facet of existence among many others. In posing inhuman forms of life as a theoretical figure for art, the article advances an aesthetics that is orientated towards "a plane of 'life' well beyond the human organism (and organic life in general)" (Colebrook, 2014, p. 220). It argues that art's peculiar capacity to compose mutant forms and qualities of 
life is what sustains it's problematic, and yet productive, tensions with philosophy and the social sciences. By embracing an immanent theory of art that breaks with the hylomorphic schema, the article aims to re-orientate arts-based research towards the inhuman affects and sensations that constitute a "life of events" (Grosz, 2017, p. 150), with the aim of opening up new potentials for "existing not as a subject but as a work of art" (Deleuze, 1995, p. 95).

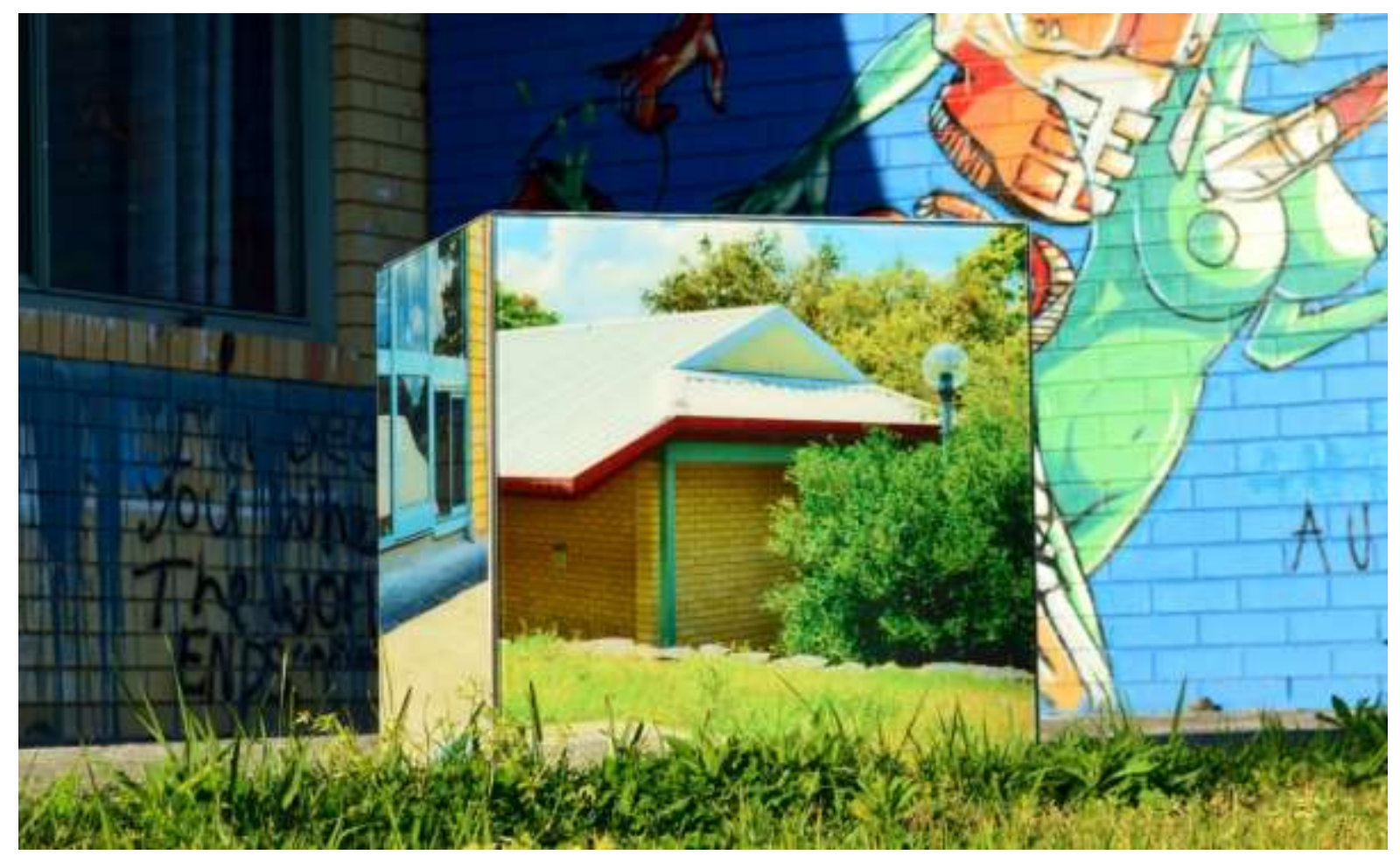

Figure 1: One of twelve interactive artworks installed by the author on SCU's Lismore Campus, as part of the States and Territories project (2013-2017).

The second part of the paper extends this inhuman theory of art through a series of artworks produced as part of the States and Territories project, which took place at Southern Cross University in Australia between 2013-2017. This project involved the collective reimagining of university learning environments through a network of interactive art installations, digital interfaces, and pedagogical interventions (see www.statesandterritories.org). Each installation has taken the form of a glass cube that maps 
the surrounding learning environment using photographic images captured from the object's singular point of view within the landscape (see Figure 1). These twelve cubes have operated as conceptual pivot points for a series of pedagogical experiments collectively produced with students and academics working in different areas across the university, including the visual arts, media studies, cultural studies, education, law, engineering, and environmental science (see Figure 2). These collaborative experiments resulted in the production of a wide variety of artefacts, including videos, images, artworks, animations, sound pieces, and texts which have subsequently been archived on the project website (see www.statesandterritories.org/archives).

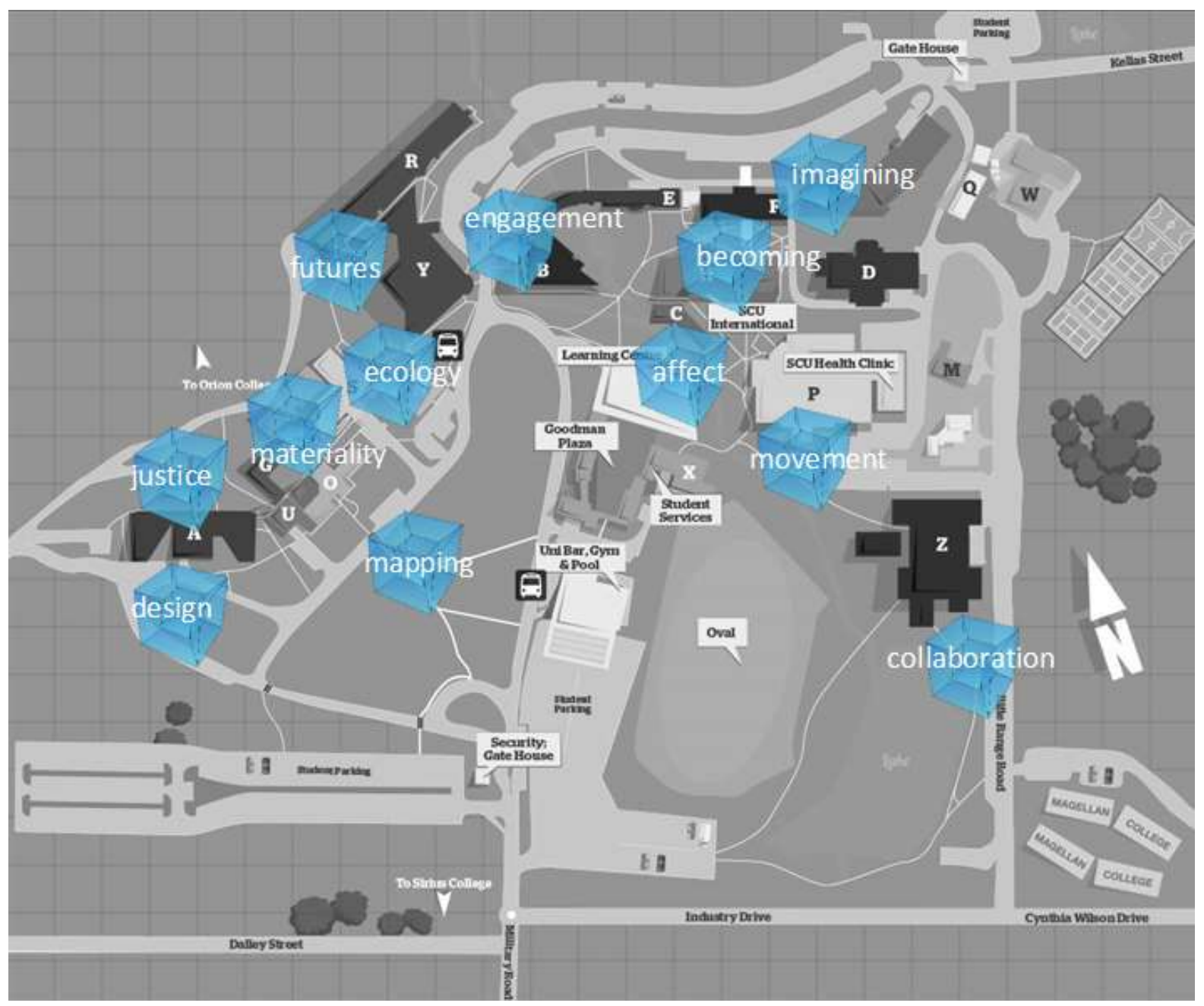

Figure 2: A map showing the network of glass cubes and associated concepts distributed across the learning environments of SCU's Lismore campus in Northern, NSW Australia 
While previous publications have addressed the theoretical and practical contributions of the States and Territories project within the fields of arts education (Rousell \& Fell, 2018) and environmental education (Rousell, 2018), this article focuses specifically on the project's engagement with contemporary art and aesthetics within a post-qualitative study of university learning environments. The latter sections of the paper focus on a specific node of the project that explored a posthumanist conceptualisation of collaboration with a group of 15 visual art students. Collaborative artworks produced by two of these students are analysed within "vignettes" which explore how artistic processes can express inhuman tendencies and produce new ecologies of relation. The paper concludes with a return to the problem of art by entertaining two possible arguments regarding the interferences and intersections between art, philosophy, and social science in post-qualitative inquiry.

\section{Post-Qualitative Responses to the Ontological Turn}

In order to outline the problematic nature of art in relation to post-qualitative research, it is firstly necessary to sketch out the contours of post-qualitative research as a response to the ontological turn in the humanities and social sciences. The ontological turn can be summarised as a shift away from epistemological debates about knowledge, verification, and evidence in order to re-open speculative questions regarding the nature of being, and the metaphysical conditions under which life, experience, and inquiry become possible (Lather \& St Pierre, 2013). Such a turn towards ontology is deemed necessary in a contemporary moment that is defined by an intractable series of "ontological crises" associated with human-induced climate change, catastrophic loss of biodiversity, bio-genetic modification, and ubiquitous mediation of life processes (Rousell, 2016). These drastic changes typify the range and extent of humanity's impact on the Earth's systems and functioning as a whole, and inaugurate the Anthropocene as a new epoch in the planet's geologic history (Crutzen \& Stoermer, 2000; Steffen et al, 2015). Ontological crises arise when the conditions of life change so quickly and 
so drastically that life itself becomes unrecognizable. The ontological turn can thus be loosely applied as a descriptor for the wild proliferation of "new" and "speculative" materialisms (Coole \& Froste, 2010; Grosz, 2017), empiricisms (Clough, 2009; de Freitas, 2016), and realisms (Shaviro, 2014) that have emerged in the humanities and social sciences over the past ten years.

Post-qualitative research has been particularly influenced by the emergence of new materialisms and new empiricisms, each of which offer alternative ontological, epistemological and methodological entry points for conducting research in educational contexts (St. Pierre, Mazzei \& Jackson, 2016). The influence of new materialisms have been felt largely through vital materialist readings of Deleuze and Guattari's philosophical oeuvre (Bennett, 2010), along with the impact of feminist materialist scholars such as Barad (2007) and Braidotti (2013). This new materialist inflection foregrounds a number of pressing onto-epistemological concerns, including: posthumanist re-imaginings of matter as a vibrant and active force, and agency as distributed across heterogeneous assemblages; bioethical and biopolitical issues raised by the confluence of life processes with emerging technologies; and increasing intersections between the materialities of everyday life and broader geopolitical, biological and social issues associated with the onset of the Anthropocene (Coole \& Froste, 2010, pp. 6-7). These new materialist concerns have made ontological work in the social sciences "increasingly urgent", as researchers struggle to respond to the new ethical problems brought forward by the rapid acceleration of material change (St. Pierre, Mazzei \& Jackson, 2016, p. 101). It is in this sense that new materialisms have injected an ontological, political, and ethical imperative into educational research to continuously invent and reinvent itself through creative experimentations with new theoretical assemblages and modalities of practice. Crucial to this development has been the crafting of new empirical approaches that equally acknowledge the 
arts, the sciences and philosophy as domains of practice that have dynamic and unpredictable effects in the material world.

In foregrounding the materiality of thought as a force that has the potential to elude representation, post-qualitative research also breaks with the "linguistic turn" engendered by poststructuralism in which human language and discourse "purportedly construct or 'represent' material realities" (MacLure, 2013a, p. 659). This has significant implications for understandings of voice and agency in post-qualitative research. If human and nonhuman agencies are always entangled and distributed within collective assemblages, then we can no longer attribute the voice of any one speaker to an inner essence or presence that is fundamentally personal, or even "human". For post-qualitative researchers, voice or agency is no longer an "innate attribute of an individual human being" (Mazzei, 2013, p. 734), but an assemblage, ecology or entanglement of human and nonhuman agencies which are distributed across the surfaces of events (Rousell, 2017). As a result, the voice or agency of the human can no longer be separated out from the cacophony of nonhuman voices that become entangled within the research assemblage. What we have come to think of as the voice, agency, intentionality, presence, essence, or "lived experience" of researchers and participants becomes a transindividual and impersonal enactment of process, a "becoming-research" that always exceeds human intentionality and consciousness. Post-qualitative inquiry therefore aims to overturn representational and hylomorphic schema predicated on a humanist metaphysics of hierarchy and depth. This has the effect of flattening out "what was assumed to be hierarchical", such that interior and exterior worlds become folded "together on the surface", with nothing "foundational or transcendental - nothing beneath or above, outside" (St. Pierre, 2013b, p. 649).

Perhaps it is here, through "the production of surfaces, their multiplication and their consolidation" (Deleuze, 1990, p. 125), that the "new" social sciences are beginning to develop 
a productive affinity with art and philosophy. But even if we accept that art, social science, and philosophy come to intersect on the enfolded surfaces of experience, this does not mean that we simply collapse each into the other and negate their differences. Rather, Deleuze and Guattari (1994) argue that art, philosophy, and science operate on different "planes" of material-semiotic production: the plane of composition (art), the plane of immanence (philosophy), and the plane of reference (science). While all three planes are predicated on creativity and experimentation as radically empirical undertakings, they differ in terms of the processes through which differences are produced on each plane: art involves the composition of percepts and affects through the force of sensation as an aesthetic figure; philosophy involves the creation of concepts by conceptual personae; and science involves the production of chains of reference that advance the function of knowledge through empirical observation (p. 199). While movements in post-qualitative research have focused extensively on the philosophical creation of concepts, including the recent posing of "concept as method" (Lenz Taguchi \& St Pierre, 2017), the ways that art's plane of composition might productively intersect with this "philosophical method" remain ambivalent. One possible response would be to pose art as an alternative way of doing philosophy, as Bogost (2015) proposes in his speculative realist account of "carpentry" (in which the art object is/does philosophy). However, this movement dissociates art from its capacity to compose aesthetic figures that are productive of living forms of sensation and feeling (or "sensibilia"), and relegates art to an abstract philosophical tool that is helpful to "think with". What happens if we refuse to reduce art to philosophy, and instead, use philosophical concepts to think art on its own aesthetic plane of composition that extends beyond the human?

The following sections focus on developing such a plane through a series of propositions offered by Deleuze and Guattari, and further elaborated by thinkers such as Massumi, Zepke, and Grosz. The aim of these sections is to establish what might be called the 
inhuman "singularity" of art as a compositional plane of production that is dynamically distinct from philosophy and social science. In doing so, specific connections are made between art and animality, territory, sensation, perception, and feeling in order to carve out a specific operational space for art within, and in relation to, post-qualitative inquiry.

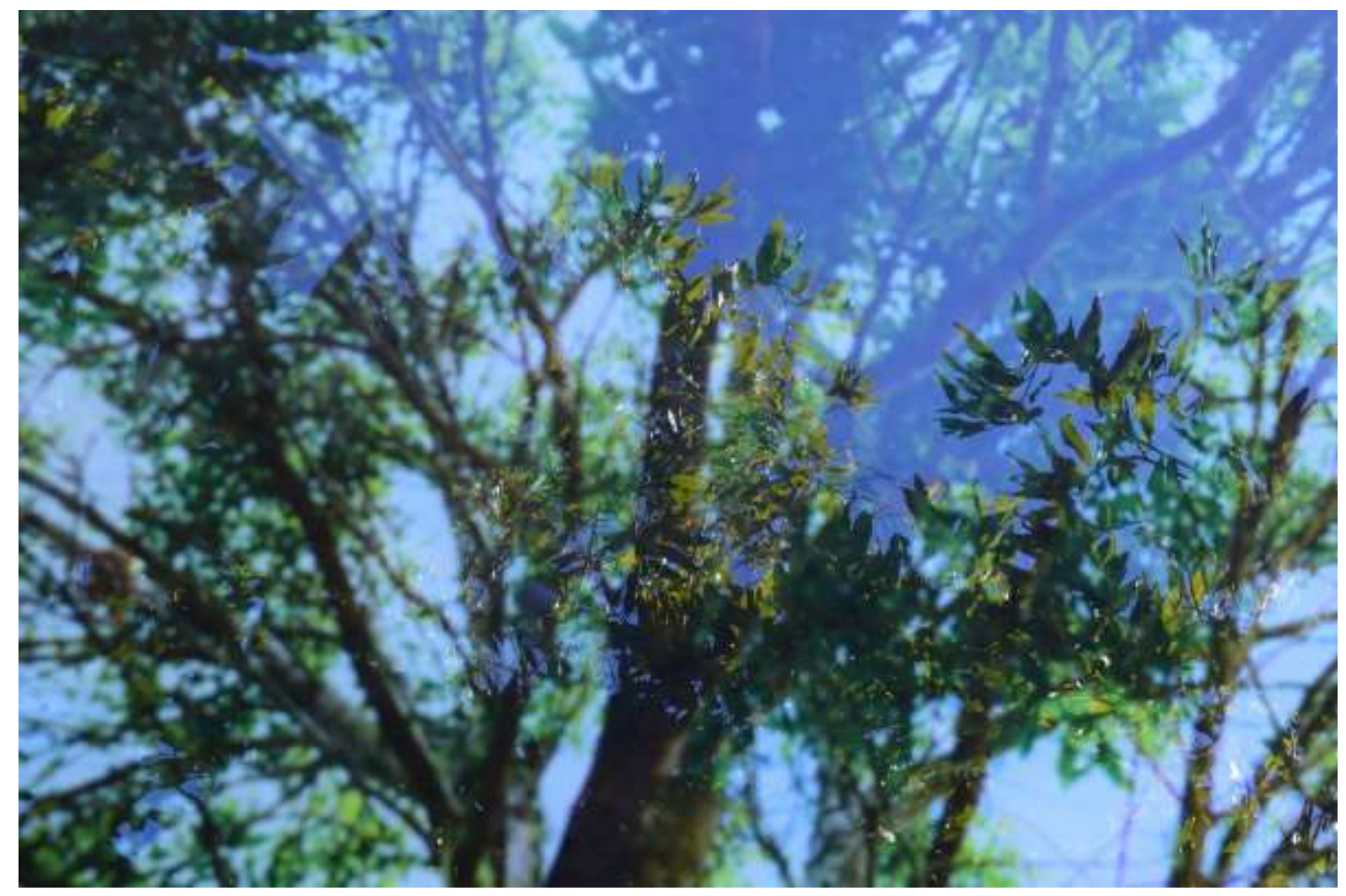

Figure 3: Surface detail of one of the author's art installations, as part of the States and Territories project (2013-2017)

\section{Towards an Inhuman Theory of Art}

In their exegesis on aesthetics in What is Philosophy?, Deleuze and Guattari (1994) set out a geophilosophical theory of art whereby the artist composes sensations that produce new experiences, instead of producing representations or interpretations of prior experience. Rather than offering novel representations of human experience, they propose that art operates as an abstract machine that creates new assemblages, as "a mechanism of creation operating at the level of the real" (Zepke, 2005, p. 2). This is the first proposition which Deleuze and Guattari 
(1994) contribute to an inhuman theory of art: that art is real and not a representation. This means that art is what it does, rather than what it means. Art operates as an abstract machine when it reroutes the function of life towards creativity and the composition of new assemblages that operate across physical, mental, social, technological and political domains. Hence, the function of art is to compose new forms of experience through creative experimentations with life's immanent potentials.

This brings us to a second proposition for art, which is that "composition, composition is the sole definition of art" (Deleuze \& Guattari, 1994, p. 192). As mentioned in the previous section, art can be seen to operate on a plane of composition through which new forms of aesthetic experience come into being. Grosz $(2008$, p. 70) further describes how the plane of composition is "the collective condition of artmaking: it contains all works of art... all the events in the history of art, all the transformations, 'styles', norms, ideals, techniques, and upheavals, insofar as they influence and express each other". In this way, the plane of composition extends all the way back to the earliest cave paintings and mythological imaginaries of ancient humans and their pre-human forbears. Yet for Deleuze and Guattari (1994, p. 184), the aesthetic plane of composition does not find its ontogenetic origins in human endeavors, but rather in the co-evolution of organisms, their territorial environments and social milieus. It is in this sense that the entire concatenation of historical and contemporary art practices, styles, forms and genres are but singular instances and recurring typologies which correspond with the composition of territorial assemblages in the animal world (Zepke, 2005, p. 65).

This introduces a third proposition, which is that art is a territorial expression of the animal rather than a personal expression of the human. Deleuze and Guattari (1994, p. 184) provide a vivid example in their description of the aesthetic practices of an Australian bird of paradise: 
Every morning the Scenopoetes dentirostris, a bird of the Australian rain forests, cuts leaves, makes them fall to the ground, and turns them over so that the paler internal side contrasts with the earth. In this way it constructs a stage for itself like a ready-made; and directly above, on a creeper or branch, while fluffing its feathers beneath its beak to reveal their yellow roots, it sings a complex song made up from its own notes and, at intervals, those of other birds it imitates; it is a complete artist. This is not a synaesthesia of the flesh but blocs of sensations in the territory colors, postures, and sounds that sketch out a total work of art. These sonorous blocs are refrains; but there are also refrains of posture and color, and postures and colors are always being introduced into refrains: bowing low, straightening up, dancing in a circle and a line of colours. The whole of the refrain is a being of sensation ... In this respect art is continually haunted by the animal.

Deleuze and Guattari's aesthetics thus rests on an ethological proposition that "the theory of the animal is bound to the theory of art" (Massumi, 2015, p. 2). Art is not considered the privilege of the human who thinks, but is haunted by the rhythms and refrains of the natural world and the creative capacities for animals to generate new forms of life through the composition of territories. "Art is the becoming-animal of the world," Zepke (2005, p. 183) writes. "It creates new forms of life outside of our stratifications, our comfortable organicism, and opinionated thoughts". Art comes to reveal the inhuman animality that stirs at the heart of the human, rather than being emblematic of any superior qualities or abilities that set humans apart from other animals. This proposition transforms conventional assumptions about biological evolution and adaptation to account for the expressive mutations, improvisations and "creative involutions" of organisms in relation to dynamic changes in shared environments and milieus (Massumi, 2015, p. 8). Art becomes a function of the inhuman element of territorial expression, as the "creative life of instinct" common to all living species. This element of 
expression "plays upon unpredictable relational effects" to produce an "aesthetic yield", resulting in a "composition animating the genesis of new forms with a life of their own" (pp. 9-10).

Rather than being confined to any sense of the "fine arts" as an all-too-human construct, Deleuze and Guattari (1994) define art in terms of the animality and intensive expression of life as the creative production of difference. Art reveals that the boundaries between "what is animal, vegetable, mineral or human in us" become indistinct when we are dealing with forces of composition (p. 174). This also implicates art in the composition of sensation, as the inhuman quality of experience that is the "immanent condition" for thought in relation to Earth and territory (Zepke, 2005, p. 187).

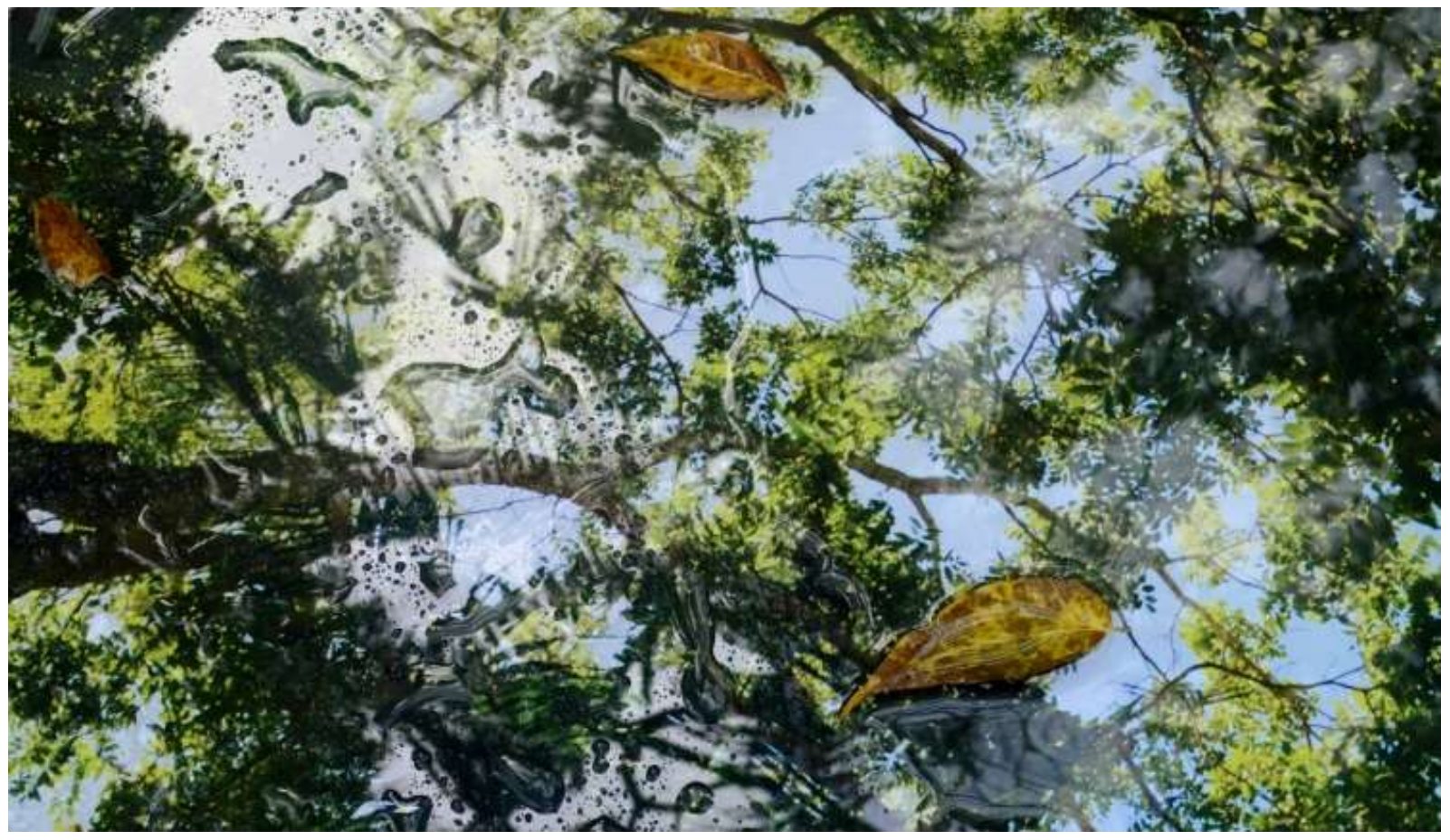

Figure 4: Surface detail of one of the author's art installations, as part of the States and Territories project (2013-2017). 


\section{Earth and Territory}

For Deleuze and Guattari (1994) works of art are driven by a creative desire to compose new blocs or compounds of sensation, as exemplified in "the birdsong, the olfactory dance of insects, the performative displays of vertebrates" (Grosz, 2008, p. 12). It is through sensation that organism and environment achieve an immediate proximity and resonance in the composition of new territories from existing milieus and refrains, or rhythms of the Earth, in order to generate new forms of life (Deleuze \& Guattari, 1987, p. 314). The composition of sensation is intimately involved with the constitution of an aesthetic territory, the framing or carving out of a space "in which sensations may emerge, from which a rhythm, a tone, colouring, weight, texture may be extracted..." (Grosz, 2008, p. 12).

The compositional power of art is such that new territories are created from the chaotic forces of the Earth (absolute disparity or difference in itself), but also that these territories can be deterritorialised, fragmented, dissolved and cast back into the chaosmos from which they were temporarily composed. "Framing and deframing become art's modes of territorialisation and deterritorialisation through sensation; framing becomes the means by which the plane of composition composes, deframing its modes of upheaval and transformation" (Grosz, 2008, p. 13). Territorialisation, in this sense, refers to the expressive process of framing the sensible forces of the earth by marking out the physical, conceptual, social, political, and technological architectures that can afford places for co-habitation (Deleuze \& Guattari, 1987, p. 311). Deterritorialisation is also complicit in this process, as the cutting edge of any territorial assemblage that catalyses the ongoing production of new thoughts, movements, practices, places, and modes of expression.

Deleuze and Guattari (1994, p. 179) describe how works of art frame the external landscape into territorial blocs of sensation, by means of "walls, but also doors, floors, windows, French windows, and mirrors which give sensation the power to stand on its own 
within autonomous frames". Art becomes an architectural envelope for framing the Earth as absolute difference in itself, in which the "cutting of the space of the earth through the fabrication of the frame is the very gesture that composes both house and territory, inside and outside, interior and landscape at once" (Grosz, 2008, p. 13). From this geophilosophical perspective, the composition of an artwork enframes the natural world within mobile architectures of experience, "ever approaching the form of the cube even as they eventually come to deform it" (p. 14). The cube therefore offers a primordial figure for the work of art as an architectural frame that composes sensory, social and environmental milieus within an incipient ecology of sensation.

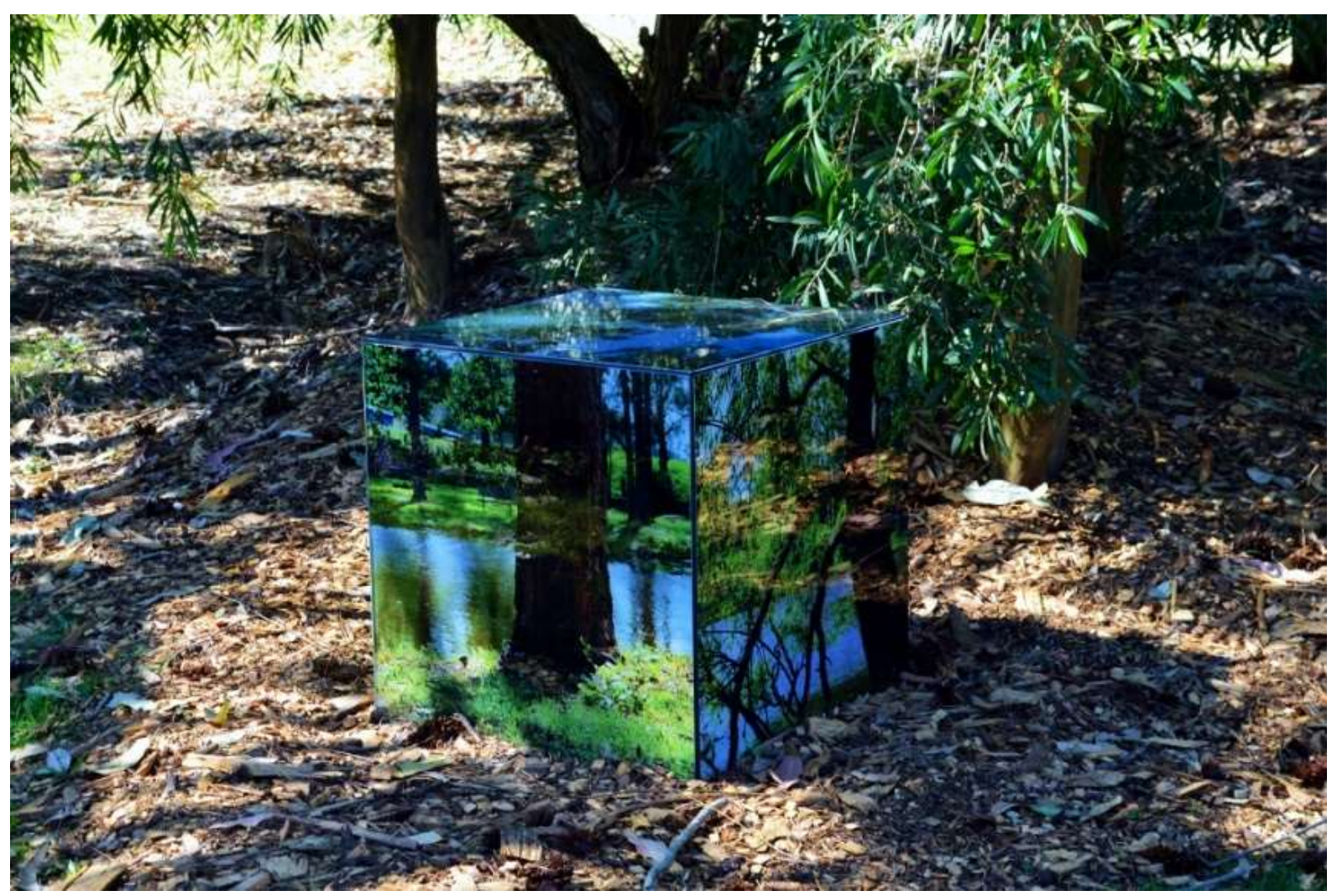

Figure 5: One of twelve interactive cubes permanently installed on the Lismore campus of Southern Cross University, as part of the States and Territories project (2013-2016)

This notion of art as compositional framing device was taken up in the States and Territories project, through the production of twelve glass cubes that de- and reterritorialise 
the milieus of a university campus in order to produce new architectures of sensation, movement, thought, and experience (see Figure 4). The cubes were created by taking photographs from specific locations within the campus environment, printing the images on sheets of toughened glass, and then re-installing the images back into the precise locations where they were captured. The return of the image back into its location of origin creates a diffraction effect between the image, the refractive surface of the glass, and the surrounding environment as it exists in a state of continuous variation and flux.

As inhuman objects with their own archival histories and routes of inheritance, the cubes continuously produce new compositions that bring images, sensations, movements, colours, objects, bodies, forms, durations, and environments together in novel and unpredictable ways. Each cube alters the sensible texture of the learning environment by cocomposing "the vibratory waves of matter, of the earth and ultimately of chaotic cosmic forces, into sensory forms that are capable of functioning as a stimulus to the nervous system" (Grosz, 2008, p. 62). This process of co-composition is what allows the cubes to operate as inhuman forms of life which generate new possibilities for sensation as felt relation. "Whether through words, colours, sounds or stone, art is the language of sensation" (Deleuze \& Guattari, 1994, p. 176). What the cubes share with all other artworks (regardless of their origins, materials, structures, meanings and modalities) is the composition and intensification of sensation as "a compound of percepts and affects" (p. 164).

\section{The Detachable Percept}

Percepts and affects can be understood as "elements" of sensation that are distilled from the deterritorialised forces of the Earth itself. These elements are plucked out from the rhythms, milieus, and refrains of the geo-physical landscape where they exist as pure potential, movement and transition (Grosz, 2008, p. 76). As the raw materials or components of sensation, percepts and affects are completely detached and autonomous from "our human perceptions 
and affections", as they essentially involve "the 'unclasping' of vision and experience from our human sensibility" (Zepke, 2005, p. 178). Percepts are distinct from "perceptions" in the phenomenological sense, referring instead to the inhuman elements of nature that render visible "the imperceptible forces that populate the world, that affect us, that make us become" (Deleuze \& Guattari, 1994, p. 169). Percepts are actually contracted from the event of perception itself, as a kind of "perception of perception". Each percept is "its own event ... a creative activity culminating in the production of an event of change" (Massumi, 2011, p. 27). From the perspective of the percept, art is the process of making the invisible visible by modulating the event of perception through "change taking place".

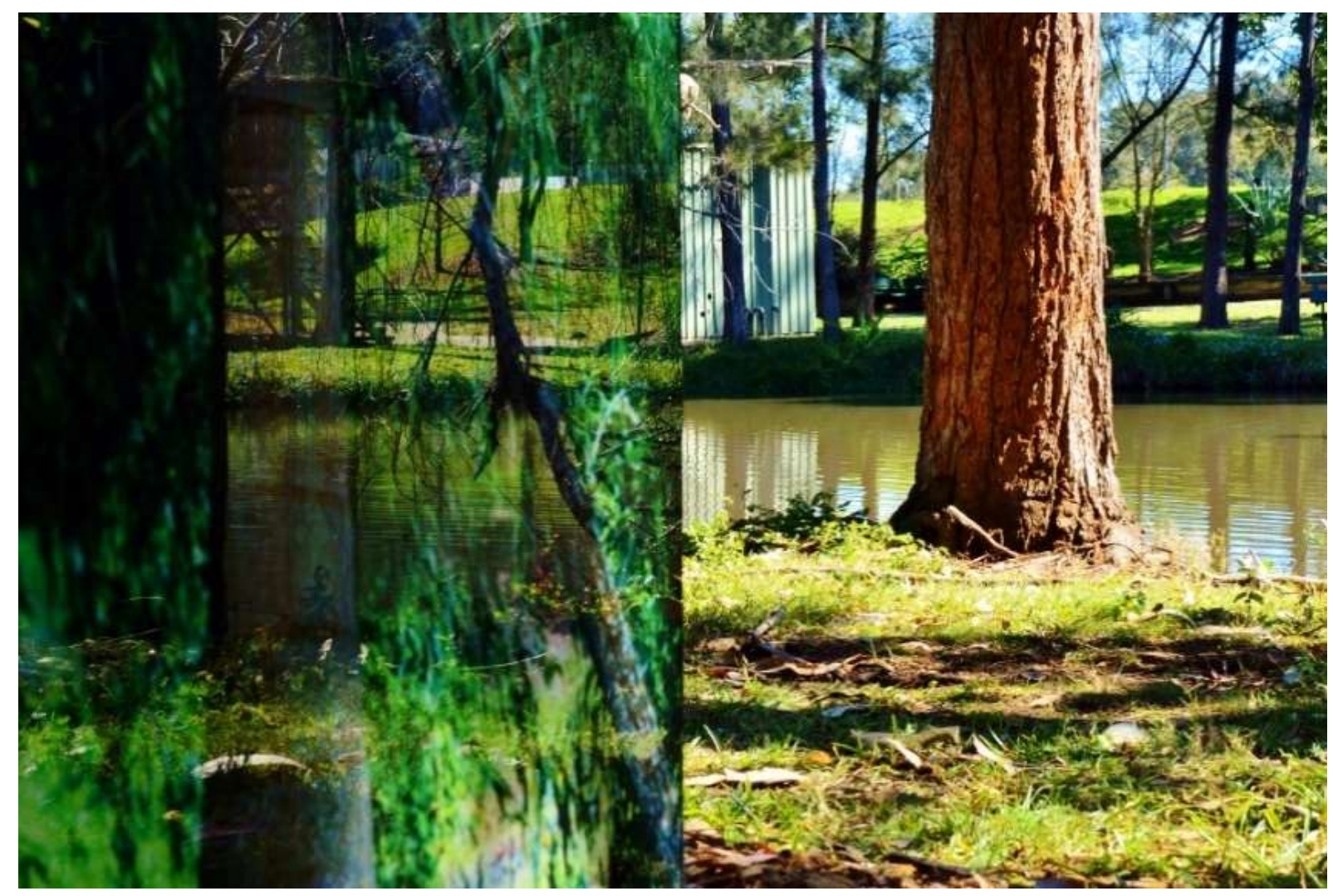

Figure 6: Detail of the cube's surface diffracting the reflection of the lake with its own image

The percept is also a critical component in the process of evolutionary accommodation or "involution" by which a living organism becomes perceptually attuned to its world, even as the surrounding environment in that world becomes attuned to the living organism (Grosz, 
2008, p. 78). The percept transforms the evolutionary function that perception contributes to survival into a resource for "something else, something more, for invention, experiment, or art" (p. 78). In other words, the evolution of animal perception for the purposes of hunting, gathering and predator evasion is rerouted by art to serve the aesthetic purposes of curiosity, imagination, mutation and the "supernormal" production of difference (Massumi, 2015). This is a very different account from the concept of "random mutation" advanced in neo-Darwinist accounts of evolution, as artful manipulations of perception come to play a significant role in the developmental plasticity of animal populations and ecological systems (Protevi, 2013; West-Eberhard, 2003). We can again consider one of the cubes created in the States and Territories project as an example of how percepts function in ways that are "lively", and yet detached or autonomous with respect to human perception. This perceptual autonomy is perhaps most evident in the capacity for the cubes to mix together multiple percepts drawn from the environments within which they are embedded. This disjunctive synthesis of multiple percepts can be seen in the details shown in Figures 5 and 6, in which the image of the duck lake (taken two years ago) and the actual duck lake (in the living present of the photograph) bleed together on the surface of the cube. The effect is even more dramatic when viewed in situ, or in this video recording of water, ducks, trees, and human movement passing across the surface of the cube: https://vimeo.com/200431518. As the hours, days, months, and seasons change, so do the differential patterns of light, precipitation, vegetation, and animal movement as they play across the surfaces of the cubes. Regardless of whether any human is present or not, the movement of percepts across the surface of the glass alters how the environment can actually be sensed, felt, witnessed, and apprehended. As an object that continuously modulates perceptual affordances within its environmental surroundings, each cube operates as an inhuman form of life that recomposes the sensible textures of the learning environment as a sensory manifold. This also makes each cube a perceptual lure and proposition for thinking- 
feeling-sensing the environment differently, in ways that are not bound by the constraints of human cognition and reflexive consciousness.

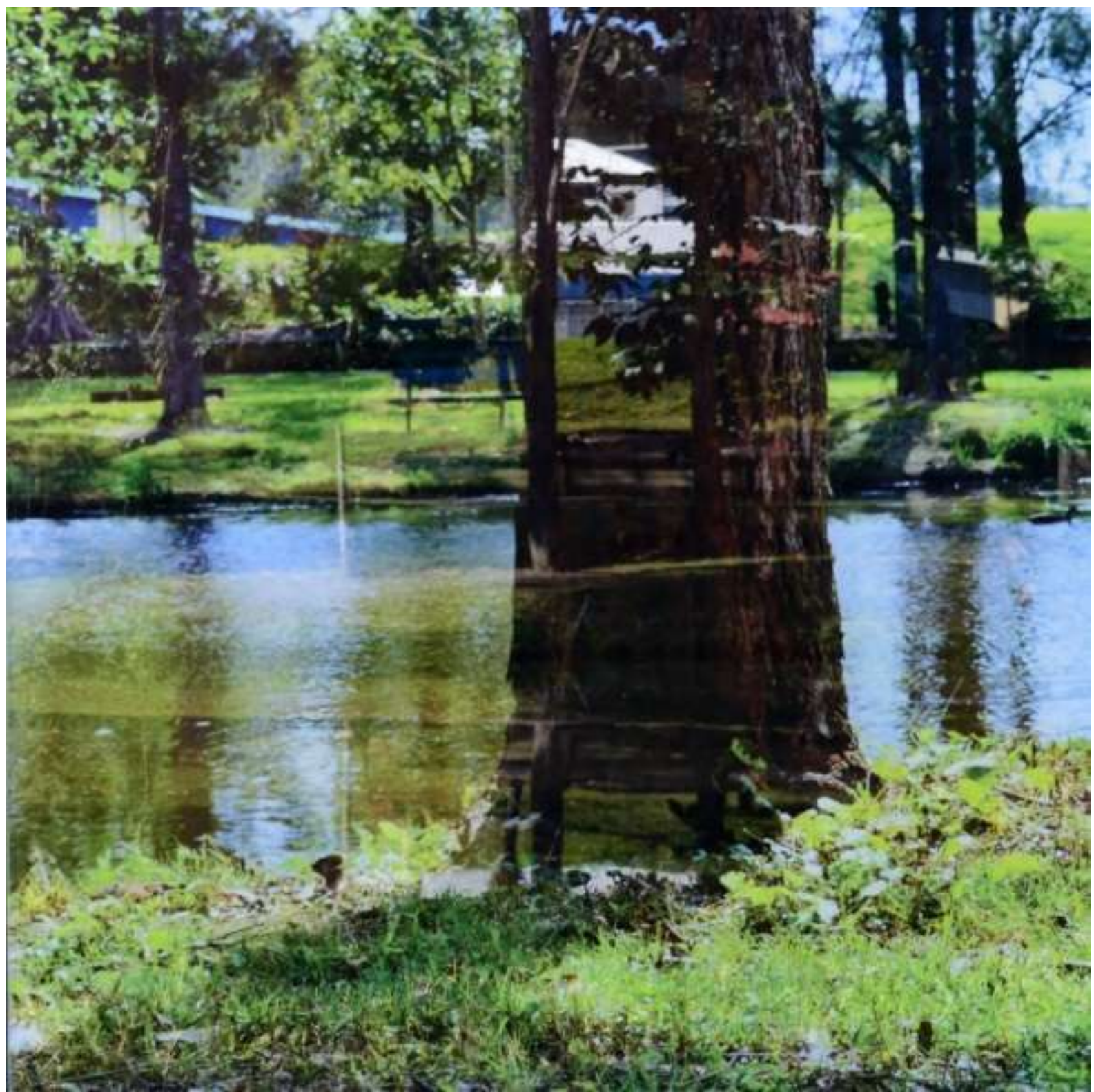

Figure 7: Detail image of the surface of the cube as it blends images of the lake with other

perceptual elements of its environmental manifold

\section{A Logic of Feeling}

In a similar sense that percepts are extracted from the event of perception, affects describe the capacities for bodies to affect and be affected by other bodies as they transition from one state 
of becoming to the next. Where percepts are tied to events of change in the perceptual field, affects are tied to events of change in pre-reflexive bodily activity. Massumi (1987, p. xvi) further defines affect as "a prepersonal intensity corresponding to the passage from one experiential state of the body to another and implying an augmentation or diminution in that body's capacity to act". This suggests that affect functions independently from (and ontologically prior to) the knowing subject, as in the way that a piece of art, or writing, or even a climatic event like a storm can impress itself on the nervous system as an aesthetic sensation that shifts the body into a different register. Affect is therefore considered pre-personal, transindividual and autonomous in its capacity to operate across bodies, territories and milieus with its own forces and tendencies that are untethered from human intentionality. Affect is felt in the passage between qualitative states because it occurs in the interstices between bodily sensation and the conscious perception and recognition of that sensation.

Recently affect has also been more closely aligned with Whitehead's (1978, p. 40) aesthetic concept of "feeling", as it relates to the process of "prehension" through which actual entities come to "feel their actual worlds". "Affective tonality", in this Whiteheadian sense, describes the subjective form or character of an event in which one entity encounters, feels, and is affected by another entity (p. 23). As Manning (2013, p. 26) notes, affect understood through Whitehead's concept of feeling becomes "the force, the lure through which a certain constellation comes to expression". This reading resituates the concept of affect within the "associated milieu" of a body in motion (Simondon, 1958), or within what Stengers (2005) calls an "ecology of practices". As the individuating force of a collective event's unfolding, "the ecology or associated milieu of the event [is] inseparable from its affect" (Manning, 2013, p. 27). This further suggests that affect is not relegated or reducible to human experience or sentience but is fundamentally inhuman in both its qualities and capacities. Shaviro (2009, p. 13, emphasis in original), for example, describes how a "falling rock 'feels' ... the gravitational 
field of the earth... it is affected by the earth, and this being affected is its experience". In this context, affect is understood as the inhuman process by which the enfolded, virtual potentiality of a physical body is felt in aesthetic relation to the shared geo-physical grounding of the Earth's gravitational field. Affect thus relates to the aesthetic qualities and capacities for an artwork to alter the qualitative tone or texture of an actualised event of encounter.

Percepts and affects are in this sense "completely complementary" in any work of art as a particular composition of sensation that is relationally and qualitatively felt (Deleuze \& Guattari, 1994, p. 182). The work of art becomes an affective and perceptual encounter that "agglomerates in the same transversal flash the subject and object, the self and other, the material and incorporeal, the before and after" (Guattari, 1995, p. 93). By working through a compositional logic of feeling, art binds percepts and affects together in order to alter the aesthetic relations between figure and ground, sensing and sensed, perceiving and perceived, feeling and felt.

\section{Collaboration after Humanism}

The States and Territories project aimed to experiment with the potentials of such a logic of feeling, using art as a modality for composing new aesthetic relations between objects, bodies, environments, concepts and more. In order to extend this inhuman theory of art into new conceptual territories, this part of the paper focuses on a node of the project associated with reimagining the concept of collaboration. This involved exploring processes of artistic collaboration with a group of 15 undergraduate visual arts students over a period of six months. The students' first encounter with States and Territories was through a central seminar presented by the author, entitled Collaboration After Humanism. Key elements of the seminar included "working in collective networks and assemblages" (Bennett 2010); "moving beyond humanist notions of individual agency and author(ity)" (Braidotti 2013); and "becoming "not 
ourselves' through more than human collaborations" (Cutcher, Rousell, \& Cutter-Mackenzie, 2015). An online interface also gave students access to a video recording of the seminar, links to relevant websites and readings, a discussion forum, and a portal for submitting text, photos, audio and video into the project's archive on collaboration (see www.statesandterritories.org/collaboration).

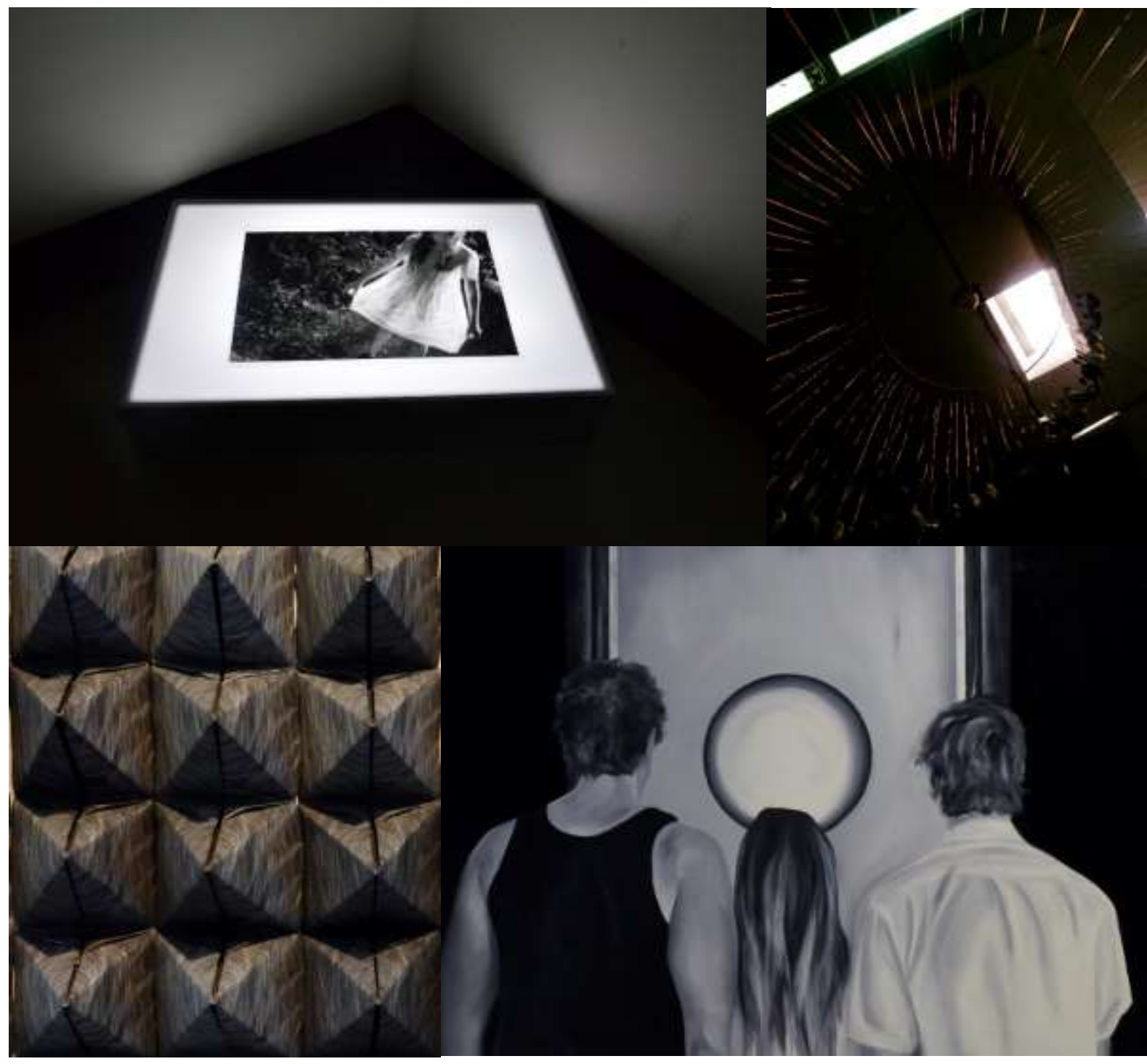

Figure 8: Montage of detail images from collaborative artworks produced by $3^{\text {rd }}$ year visual arts students as part of the States and Territories project

Following the Collaboration After Humanism seminar, students began experimenting with various processes of collaboration while using iPads to record their material studio 
practices and conceptual thinking at various points during the semester. The students also took on the curatorial process of producing an exhibition of their collaborative artworks, which forced them to negotiate each other's practices in relation to the formal constraints of space, and enabled them to enter into an expanded political ecology associated with a public encounter. As it unfolded over the course of the semester, these collaborative art experiments yielded a large amount of video, audio, photographic and textual material as collectively generated by the students and researchers. These materials then served as the basis for a multisensory cartography that maps various elements of this node of the project, and which can be accessed in the archive hosted on the States and Territories website (see www.statesandterritories.org/collaboration-archive).

While further details regarding the curricular and pedagogical implications of this process have been published elsewhere (Rousell \& Fell, 2018), this paper draws together two vignettes of collaborative artworks which help to advance the inhuman theory of art developed in the previous sections. The figure of the "vignette" is used as a form of analytic experimentation with how data can be sensed, felt, and thought differently through processes of relational encounter within research events. This approach connects with previous usages of the vignette as "rupture" (Masny, 2014) or "window" (Gale, 2014) into the research assemblage, while also applying a distinctly "diagrammatic" and "speculative" treatment of the vignette as a partial facet or surface of a more widely distributed constellation of events (Rousell, 2017). The first vignette focusses on a collaboration between an art student and her grandmother that resulted in an irrational "pairing" of disparate species, images, percepts, and sensations. The second vignette analyses a collaboration between an art student and her brother, which produces new insights into "molecular" processes of collaboration that operate across multiple scales and temporalities of experience. 


\section{First Vignette: Exchanging Particle Signs}

In this vignette a visual arts student collaborates with her grandmother to create an artwork entitled Our Favourite Things. Their process involves going through old magazines and clipping out images of things that capture their interest, appreciation, and enjoyment. "For some reason our interests are drawn towards certain objects, animals, places, tastes, sounds, smells and colours", the student says. These clippings are then reassembled into a series of collages in which "things are paired by default, humour, contrast, and then positioned to become blurred, obvious, interesting, harmonious, and questionable".
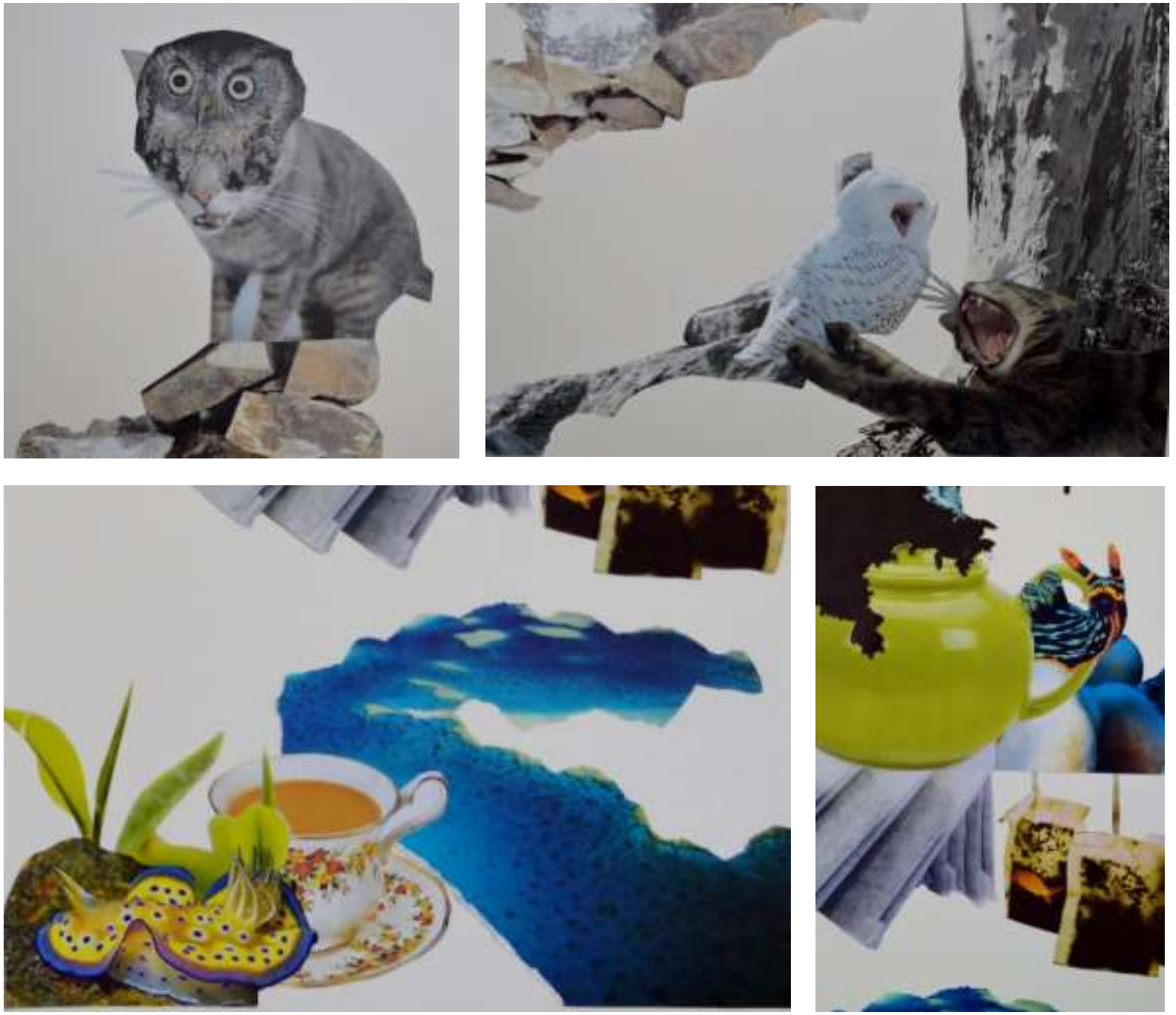

Figure 9: Detail from Our Favourite Things 
Through this process, entities that have no logical correspondence or causal relationship are 'paired' in order to produce strange hybrids and amalgamations: nudibranchs find affinity with cups of tea; owls are paired with cats; clouds are paired with exotic fruits; and flowers are paired with the colour green (see Figure 4). The qualities and tendencies of these various couplings are also inscribed below the collaged images, such that the nudibranch's "feathery tuft and pair of tentacles" are paired with "3000 varieties" of tea and their propensity to be “enjoyed in company".

While this collaborative process begins with a focus on what might called "personal interest", the act of cutting and pairing detaches these interests and places them on a mutual plane of composition, allowing them to form new relations and capacitate different kinds of events. The inhuman process of pairing which the artists perform resonates with Deleuze and Guattari's account of "becoming-animal", as a rhizomatic exchange of "corpuscular emissions" or "particle signs". The exchange of particle signs between species results in "the aparallel evolution of two beings which have absolutely nothing to do with each other" (Chauvin, cited in Deleuze \& Guattari, 1987, p. 10). This process of aparallel evolution is exemplified by the symbiotic relationship between the wasp and the orchid as catalysed by a mutually deterrorialising process: the becoming-wasp of the orchid, and the becoming-orchid of the wasp. Neither wasp nor orchid bear any resemblance to one another, and neither does one imitate the other's behaviour. Rather, they enter into a machinic wasp-orchid assemblage as a becoming-animal that creates a new type of collaborative reality.

The exchange of particle signs between species can also be linked to more recent developments in postgenomic biology and developmental ecology (Protevi, 2013). Rather than genes being fixed and immutable biological components of a given socioecological system, there is now evidence that gene expression is dynamically regulated and even "exchanged" between organisms in response to changing sensory, social, and environmental conditions 
(West-Eberhard, 2003). The exchange of particle signs is also exemplified through the type C virus which has been found to affect both baboons and domesticated cats, or other instances of bird or swine flus that affect human populations. In these instances, the virus "can take flight, move into the cells of completely different species, but not without bringing with it 'genetic information' from the first host" (Deleuze \& Guattari, 1987, p. 10). These biogenetic examples of particle exchange suggest that these artworks involve not only a collaboration between the student and her grandmother, but also a collaboration amongst a host of different entities that contribute their perceptible qualities and "particle signs" to the compositions.

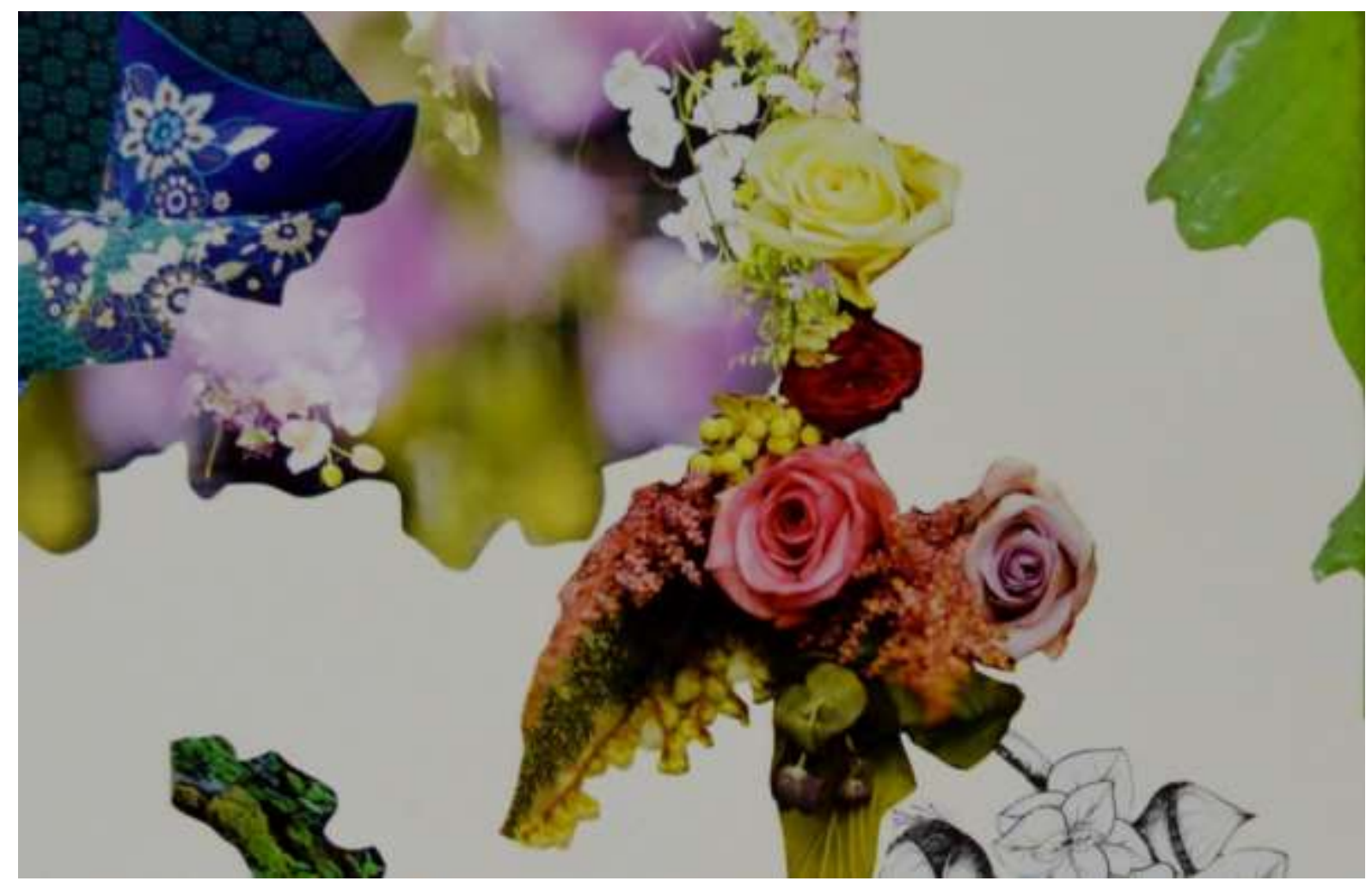

Figure 10: Detail image from Our Favourite Things

From this speculative perspective, entities as ontologically disparate as a cloud, a nudibranch, or the colour green can be seen to enter equally into the process of collaboration through the "particles of sensation" which they emit and contribute to a given composition. The student goes on to describe her experience of collaboration with her grandmother as a 
process of "bringing together differing and yet similar minds ... so we were bringing together both of our worlds, and placing them on the same page together". This process involves the interleaving of differential perceptual faculties, as her grandmother "has macular degeneration so she'll just put like a random blob in the centre of something". Indeed, one of the most interesting features of these works is the heightened sense of contrast that is produced through the layering of blurred and high-resolution imagery, generating a field of multiple perceptual modalities that are enfolded on a single surface. In this way, the fuzzy sections of each collage render an abstract window into "what it's like for Nan to see an image [as] just like this distorted, grey blur". This suggests that there is an inhuman entanglement of differential modes of perception within the sensory manifold of a collaborative process as it appears on the surface. The collage gives us a vague sense of what it feels like to perceive the actual world differently at the same time, as a multiplicity of perceptual manifolds that attune and attenuate differently within a shared field of experience.

\section{Second Vignette: Molecular Collaborations}

Although the first vignette effectively stretches the concept of collaboration to include the exchange of particles signs and perceptual manifolds, it also raises the question of how the process of collaboration enables bodies to transition between different perceptual modalities, scales, and temporalities. This question is explored through the concept of the "molecular" in this second vignette, in conversation with an art student who conducted an extended study of plant cells in collaboration with her twin brother. The student explains how she explored "the delicate nature of cell structures by making them large and then compressing them down". This involved a range of different artistic processes combining various types of printmaking, sculptural forms made from tissue paper, and optical lenses that variously function to magnify or contract these other elements depending on the movements of the viewer (see Figure 5). 

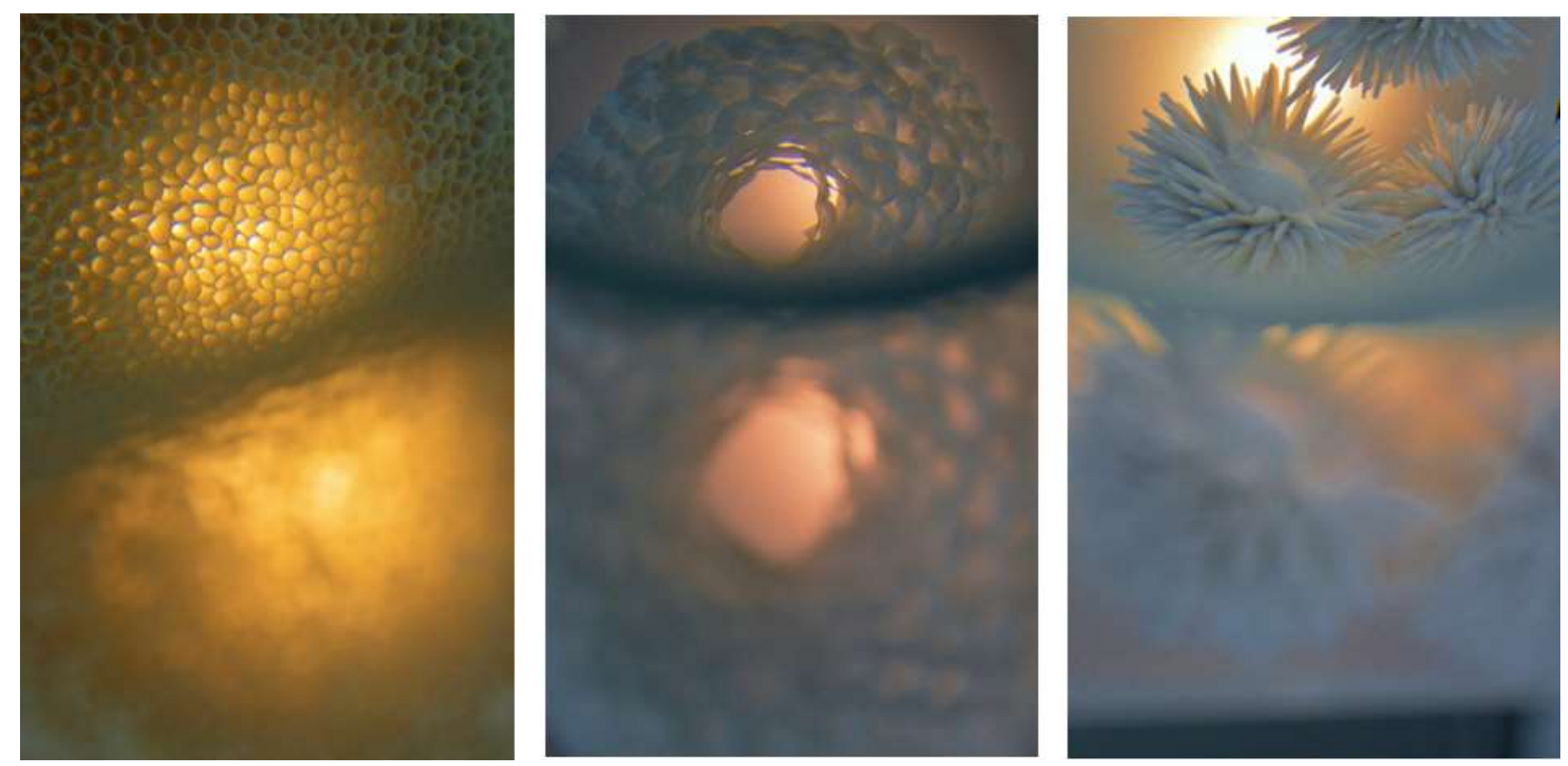

Figure 11: Cellularum (details), mixed media, 2015

The student describes this not only as an inquiry into the structures of cells, but also as an exploration of "the relationship between and of us ... the micro and macro of us". The structures and relationships between cells are thus associated with the biogenetic and familial relations between herself and her brother, such that the molecular can be understood as an affective line of perceptual and somatic movement that transitions seamlessly across the microscopic and macroscopic surfaces of events. The boundaries between figure|ground and inside|outside are therefore also smudged, blurred, and folded onto the reticulated surface of the artwork, like an origami flower that keeps going out of focus while retaining its topological manifold.

This vignette helps to develop a molecular understanding of collaboration that is not defined by any particular scale of analysis, but rather inheres to the transitive movement of percepts, affects and sensations across scales and intensities of experience. As Deleuze and Guattari write (1987, p. 275), "all becomings are molecular: the animal, flower, or stone one becomes are molecular collectivities, haecceities, not molar subjects, objects or forms that we know from the outside and recognise from experience, through science, or by habit". The 
molecular is associated with the fluid and open-ended movements of collective events and multiplicities that are produced by the interweaving of different modes of existence, and are therefore irreducible to any fixed category of form, function, identity, or being. The molar, on the other hand, is associated with fixed categories such as those that define an age group, sex, gender, race, species, domain, or other "type" of existence. Where the molar can be envisaged as a nested series of galaxies, solar systems, planets, ecosystems, societies, animals, humans, cells, atoms, and subatomic particles which (more or less) collaborate to produce experience, molecular collaborations are able to pass seamlessly through any of these as a dynamic series of movements, forces, and tendencies which are not reducible to scale or ontological category.

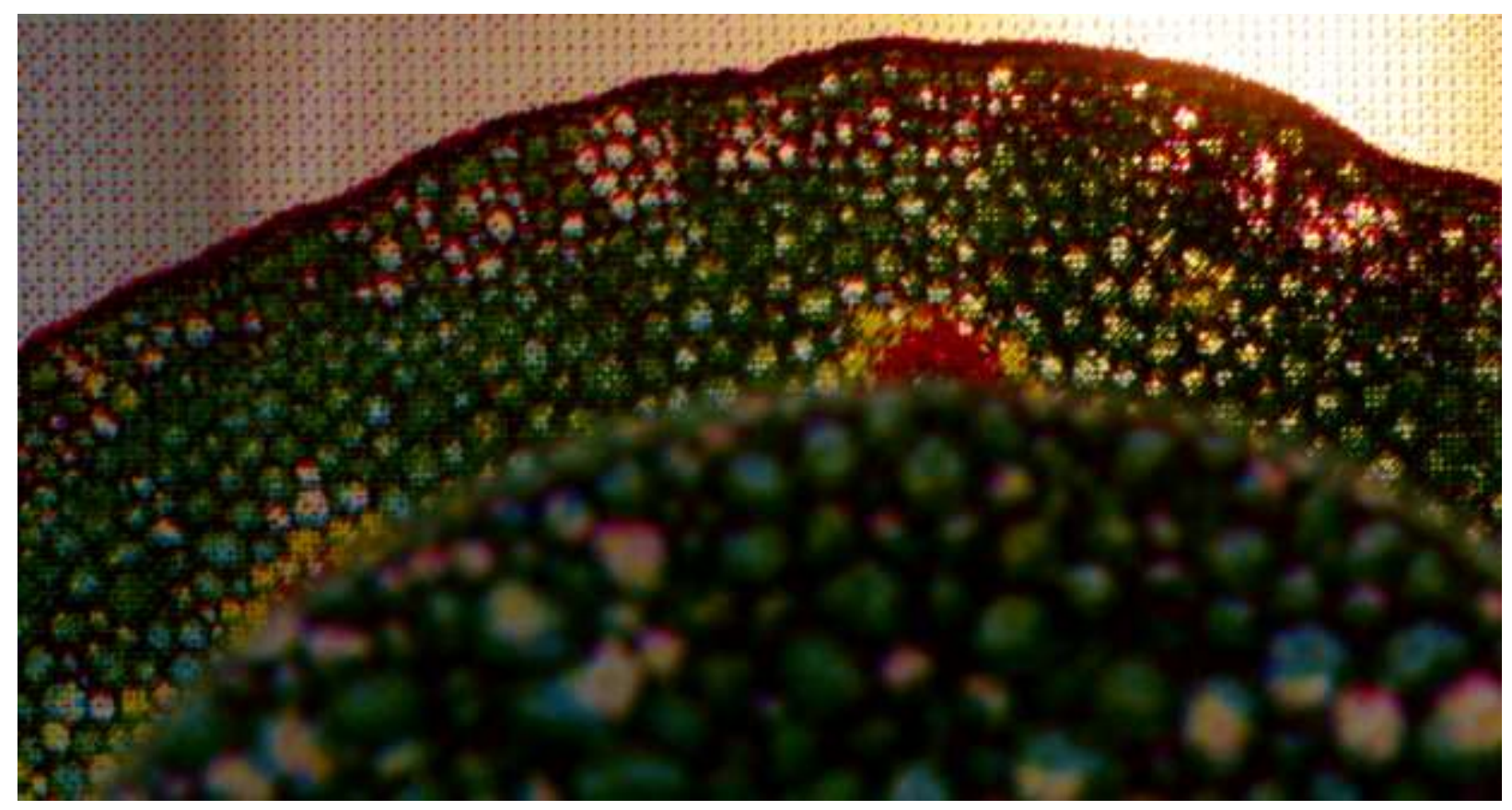

Figure 12: Detail view from Cellularum

The student's work provides an interesting example of this distinction, in which a molecular collaboration can be understood as simultaneously incorporating the micro and the macro within the inhuman arc of a life, such that the compositional elements and modes of an event can be magnified and contracted continuously without losing its consistency as a process of becoming. The notion of molecular collaboration therefore provokes a shift in how a 
"collective" or "community" is understood. In foregrounding inhuman processes of relationality and becoming over any fixed category of being, the collective is no longer understood as simply an aggregate of beings, even if that aggregate is democratically extended to include both human and nonhuman actants (as in the work of Latour, 2004). A molecular collective is perhaps better understood in terms of what Brunner (2014) calls an "ecology of relation", in which the units that compose the collective are not individual beings but relations of "movement, tendency, or force - a becoming" (p. 66). The collective that is composed and expressed through a molecular collaboration is more so the result of a "field effect" arising from an ecology of relation as it comes together, rather than the molar result of two or more actants interacting to produce a shared product (p. 67).

As shown in further details of the student's work (see Figure 11), a molecular collaboration generates a zone of indeterminacy that moves between multiple bodies, scales and temporalities, again creating a series of thresholds, smudges, or blurs between multiplicities. In this work of art, the movement across the micro and the macro is affected be adjusting one's body and positioning in relation to optical lenses, which also become haptic interfaces for manipulating perception as a molecular event that includes the viewer in the formation of new ecologies of relation.

\section{Returning to the Problem of Art}

In returning to the problem of art in relation to post-qualitative research, it is perhaps helpful to summarise the speculative propositions that have been posed with regards to an inhuman aesthetics. Drawing primarily on the work of Deleuze and Guattari, this article has proposed that a) art is real and not a representation; b) art is a composition of sensations (affects and percepts); c) art is an expression of the relation between animal and territory; d) art is a problem, rather than a solution; and e) art creates new forms and potentials of life within ecologies of 
relation. This inhuman theory of art has been extended through the analysis of two collaborative artworks produced by visual art students attending a regional university. These works emphasise collaboration as a process through which bodies, feelings, movements, environments, perceptions, colours, sounds, and more enter into the production of a disjunctive synthesis, thus generating new compositions of sensation and thought. Each vignette moves the inquiry in directions that were previously imperceptible and inconceivable, altering the trajectory of thought and mutating the material possibilities for felt relation and experience. The artworks produced are expressions of inhuman tendencies, in the sense that they are not reducible to humanist conceptions of voice, identity, personality, or narrative. Rather than offering representations of predetermined forms of human experience, these works generate inhuman forms through which life can be felt, sensed, thought, and articulated differently. The outcome of such collaborative artmaking is perhaps best understood in terms of a diagram, palimpsest, or cartography that allows new forms of life to become sensible on the surface of a collective event in the making (Rousell \& Fell, 2018).

While this paper has theorised art in ways that are largely compatible with many of the founding gestures and propositions of post-qualitative educational research, it also attempts to confront the problem of how art does or does not intersect with philosophy and the social sciences within such work. In attempting to "diagnose" this as a problem with which this very article is complicit, two potential arguments, readings, or "trajectories" of the problem are addressed in this concluding section. One trajectory could argue that this paper has fallen into the very trap that it laid at the outset, namely, that it has produced a hybridised piece of work that is not quite art, not quite philosophy, and not quite social science. This trajectory would suggest that encounters between art and post-qualitative research generally produce hybrid forms of scholarship that entangle concepts, theories, practices, affects, percepts, bodies, objects, events, and more. This can result in a kind of "intra-active" (Barad, 2007) morass or 
compost heap (Haraway, 2016) within which new forms of scholarship ferment. While "composting" practices have the potential to unleash novel possibilities for educational research as a transdisciplinary field, the transgressive potentials of art are often diluted or defanged through such processes. For instance, there is a tendency for hybrid forms of educational scholarship to remain dominated by theoretical texts, perhaps scattered with images of art or other media which are used to support or illustrate particular concepts. Under these circumstances, the work of art becomes flattened, blended, manipulated, and decomposed in order to serve the purposes of theory, which takes on a masterful role in determining what matters in a piece of post-qualitative scholarship. From this point of view, post-qualitative scholarship is recognised by its capacity to extrapolate a particular body of theory, and use philosophical concepts to interrogate or affirm various social, material, and semiotic phenomena. Art may be enlisted as a (more or less) key ingredient, but the fundamental problem which art poses to post-qualitative inquiry often remains unacknowledged or simply buried under the rhetorical weight of theoretical language.

A second trajectory therefore suggests that post-qualitative researchers attempt to distinguish the elements of art, philosophy and social science in their scholarship, and evaluate how these elements interfere, problemetise and intersect with each other in novel ways. But how can we distinguish the role of each element in the inquiry? One of the suggestions we can draw from Deleuze and Guattari is to question how each element stands up on its own, or how it contributes its own particular refrain within the inquiry, whether through harmonic or disjunctive resonance with other elements. From this perspective, we might question whether there are artistic elements embedded in the inquiry that might stand alone, in a gallery or public space, and produce new forms of sensation and feeling for those who encounter them. We could then go on to question whether new philosophical concepts or conceptualisations are produced in the work, and whether these philosophical elements contribute to current debates and 
developments within a body of theory. Lastly, there would be the question of whether the work contains an element of social science that might stand up as a chain of references that is accountable to empirical events and social realities. Notwithstanding current trends towards commentary and critique as social science, this question would inquire into how the work produces novel renderings of the social through references to empirical actualities. Overall, this process involves distinguishing artistic, philosophical, and scientific elements by asking different questions of the inquiry itself, allowing methodological problems to arise and proliferate across and between elements, and becoming aware of how each element can variously obscure, magnify, disrupt, contrast, exceed, activate, or strengthen the import of other elements. By refusing to reduce one element to any other within the research assemblage, the inquiry is kept in suspension, resisting resolution by continuously reorientating towards the production of new forms and potentials of life.

While the arguments presented above offer two diverging and yet tangential perspectives on the problem of art in post-qualitative research, there are of course many other possible ways to frame and attack the problem. The core argument of this paper, however, is that the problem should be actively acknowledged and tackled rather than treating art as a solution to the post-qualitative crisis of methodology. If art is to be engaged as an equal partner in post-qualitative research then it must be taken up just as vigorously as the philosophical or sociological elements of the work. Post-qualitative researchers should become ready to explain what a work of art is, the potentials of what art can $d o$, and perhaps most importantly, how art does its work in the study. This may involve a willingness for post-qualitative educational researchers to engage more closely with art theory and history, or to collaborate with emerging or established artists whose practices are conceptually challenging and technically innovative.

Lastly, it is important to note that the boundaries between art, philosophy, and social science are not fixed or rigid, but should remain flexible in allowing for ongoing suspensions, 
interpenetrations, and interferences between the planes of composition, consistency, and reference. These are described by Deleuze and Guattari (1994, p. 217) as extrinsic interferences in which the elements and techniques of each discipline remain on their own planes; intrinsic interferences in which elements and techniques slip and slide across planes; and nonlocalisable interferences, in which each plane connects, necessarily, to its own outside. This last case refers to the paradoxical necessity for art to connect with nonart, philosophy with nonphilosophy, and science with nonscience. It is in these negative spaces outside of thought and even outside of practice that "philosophy, science and art become indiscernible, as if they shared the same shadow that extends itself across their different nature and constantly accompanies them" (p. 218). Perhaps it is in this shadow that new forms of post-qualitative inquiry might be germinated, in the dark and imperceptible spaces where art, philosophy, and social science can inoculate and activate their inhuman tendencies and forms.

\section{References:}

Barad, K. (2007). Meeting the universe halfway: Quantum physics and the entanglement of matter and meaning. Durham, NC: Duke University Press.

Bennett, J. (2010). Vibrant matter: A political ecology of things. Durham, NC: Duke University Press.

Bogost, I. (2015). The aesthetics of philosophical carpentry. In R. Grisin (Ed.), The nonhuman turn (pp. 81-100). Minneapolis: University of Minnesota Press.

Bolt, B. (2013). Toward a "new materialism” through the arts. In E. Barrett, \& B. Bolt (Eds.), Carnal Knowledge: Towards a 'New Materialism' through the Arts (pp. 1-14). London, UK: I.B. Tauris.

Boulton-Funke, A. (2014). A critique and a proposal: A/r/tography and arts-based research as 
a methodology of intuition. Visual Inquiry, 3(2), 207-221.

Braidotti, R. (2013). The posthuman. Cambridge, UK. Polity Press.

Brunner, C. (2014). Ecologies of relation: Collectivity in art and media (unpublished PhD thesis). Retrieved from http://spectrum.library.concordia.ca/979665/.

Coole, D., \& Frost, S. (2010). Introducing the New Materialisms. In D. Coole \& S. Frost (Eds.), New Materialisms: Ontology, Agency and Politics (pp. 1-43). London, UK: Duke University Press.

Crutzen, P. J., \& Stoermer, E. F. (2000). The 'Anthropocene'. Global Change Newsletter 41, $17-18$.

Cutcher, L., Rousell, D., \& Cutter-Mackenzie, A. (2015). Findings, Windings and Entwinings: Cartographies of collaborative walking and encounter. The International Journal of Education Through Art, 11(3) pp. 449-458.

de Freitas, E. (2016). The new empiricism of the fractal fold: Rethinking monadology in digital times. Cultural Studies - Critical Methodologies, 16(2), 224-234.

Deleuze, G. (1990). The logic of sense (M. Lester, Trans.). New York, NY: Columbia University Press.

Deleuze, G., \& Guattari, F. (1987). A thousand plateaus: capitalism and schizophrenia (B. Massumi, Trans.). Minneapolis: University of Minnesota Press.

Deleuze, G., \& Guattari, F. (1994). What is philosophy? (H. Tomlinson \& G. Burchell, Trans.). New York, NY: Columbia University Press.

Demuth, C. (2015). "Slow Food" Post-Qualitative Research in Psychology: Old Craft Skills in New Disguise? Integrative Psychological and Behavioral Science, 49(2), 207-215.

Gale, K. (2014). Moods, tones, flavors: Living with intensities as inquiry. Qualitative Inquiry, 20(8), 998-1004.

Grosz, E. (2008). Chaos, territory, art: Deleuze and the framing of the earth. New York, NY: 
Columbia University Press.

Grosz, E. (2017). The incorporeal: Ontology, ethics, and the limits of materialism. New York, NY: Columbia University Press.

Guattari, F. (1995). Chaosmosis: An ethico-aesthetic paradigm. Sydney, NSW: Power Publications.

Guyotte, K. (2017). Encountering Bodies, Prosthetics, and Bleeding: A Rhizomatic Arts-Based Inquiry. Reconceptualizing Educational Research Methodology, 8(3).

Haraway, D. J. (2016). Staying with the trouble: Making kin in the Cthulucene. Durham, NC: Duke University Press.

Heimans, S. (2016). Fieldwork in philosophy, emancipation and researcher dis-position: A post-qualitative research exemplar. Qualitative Research Journal, 16(1), 2-12.

Hernández, F. H., Gil, J. M. S., \& Coscollola, M. D. (2018). Cartographies as spaces of inquiry to explore teachers' nomadic learning trajectories. Digital Education Review, (33), 105119.

Holbrook, T., \& Pourchier, N. M. (2014). Collage as analysis: Remixing in the crisis of doubt. Qualitative inquiry, 20(6), 754-763.

jagodzinski,j., \& Wallin, J. (2013). Arts-based research: A critique and a proposal. Rotterdam: Sense Publications.

Johansson, L. (2016). Post-qualitative lines of flight and the confabulative conversation: a methodological ethnography. International Journal of Qualitative Studies in Education, 29(4), 445-466.

Kuby, C. R., Aguayo, R. C., Holloway, N., Mulligan, J., Shear, S. B., \& Ward, A. (2016). Teaching, troubling, transgressing: Thinking with theory in a post-qualitative inquiry course. Qualitative inquiry, 22(2), 140-148.

Lather, P. (2013). Methodology 21: What do we do in the afterward? International Journal of 
Qualitative Studies in Education, 26(6), 634-645.

Lather, P., \& St. Pierre, E. A. (2013). Post-qualitative research. International Journal of Qualitative Studies in Education, 26(6), 629-633.

Latour, B. (2004). Politics of nature (C. Porter, Trans.). Cambridge, MA: Harvard University Press.

Latour, B. (2013). An inquiry into modes of existence: An anthropology of the moderns (C. Porter, Trans.). Cambridge, MA: Harvard University Press.

MacLure, M. (2013). Researching without representation: Language and materiality in post-qualitative methodology. International Journal of Qualitative Studies in Education, 26(6), 658-667.

Manning, E. (2013). Always more than one: Individuation's dance. Durham, NC: Duke University Press.

Masny, D. (2014). Disrupting ethnography through rhizoanalysis. Qualitative Research in Education, 3(3), 345-363.

Massumi, B. (1987). Notes on the translation and acknowledgements. In G. Deleuze \& F. Guattari, A thousand plateaus: capitalism and schizophrenia (pp. xvi-xx). Minneapolis: University of Minnesota Press.

Massumi, B. (2011). Semblance and Event: Activist philosophy and the occurrent arts. Cambridge, MA: Massachusetts Institute of Technology.

Massumi, B. (2015). The supernormal animal. In R. Grisin (Ed.), The Nonhuman Turn (pp. 1-18). Minneapolis: University of Minnesota Press.

Mazzei, L. A. (2013). A voice without organs: Interviewing in posthumanist research. International Journal of Qualitative Studies in Education, 26(6), 732-740.

Morton, T. (2013). Hyperobjects: Philosophy and ecology after the end of the world. Minneapolis: University of Minnesota Press. 
Protevi, J. (2013). Life, war, earth: Deleuze and the sciences. Minneapolis: University of Minnesota Press.

Rousell, D. (2016). Dwelling in the Anthropocene: Re-imagining university learning environments in response to social and ecological change. The Australian Journal of Environmental Education, 32(2) pp. 1-20.

Rousell, D. (2017). Mapping the Data Event: A posthumanist approach to art|education|research in a regional university. In L. Knight \& A. Cutcher (eds.). Arts, Research, Education: connections and directions. New York: Springer International Publishing.

Rousell, D., \& Fell, F. (2018). Becoming a work of art: Collaboration, materiality and posthumanism in visual arts education. International Journal of Education through Art [special issue on Speculative Realism(s)], 14(1), 91-110.

Rousell, D., Laszcik, L., Irwin, R., \& Cook, P. (2018). Propositions for an environmental arts pedagogy: A/r/tographic experimentations with movement and materiality. In CutterMackenzie, A., Malone, K., and Barrett-Hacking, E. (eds.), International Research Handbook on ChildhoodNature. The Netherlands: Springer.

Simondon, G. (1958). On the mode of existence of technical objects (N. Mellamphy, Trans.). Paris: Aubier.

Snaza, N., \& Weaver, J. (2015). Introduction: Education and the posthumanist turn. In N. Snaza, \& J. Weaver (Eds.), Posthumanism and educational research (pp. 1-16). New York, NY: Routledge.

Shaviro, S. (2009). Without criteria: Kant, Whitehead, Deleuze, and aesthetics. Cambridge, MA: MIT Press.

Shaviro, S. (2014). The universe of things: On speculative realism. Minneapolis: University of Minnesota Press. 
Sinner, A. (2017). Cultivating researchful dispositions: a review of a/r/tographic scholarship. Journal of Visual Art Practice, 16(1), 39-60.

St. Pierre, E.A. (2011) Post qualitative research: The critique and the coming after. In N.K. Denzin \& Y.S. Lincoln, (Eds.), The SAGE handbook of qualitative research. (pp. 611626). Thousand Oaks, CA: SAGE.

St. Pierre, E. A. (2013). The posts continue: Becoming. International Journal of Qualitative Studies in Education, 26(6), 646-657.

St. Pierre, E.A. (2016). Curriculum for new material, new empirical inquiry. In N. Snaza, D. Sonu, S.E. Truman, \& Z. Zaliwska (Eds.), Pedagogical matters: New materialisms and curriculum studies (pp. 1-12). New York, NY: Peter Lang.

St. Pierre, E. A., Jackson, A. Y., \& Mazzei, L. A. (2016). New empiricisms and new materialisms: Conditions for new inquiry. Cultural Studies $\leftrightarrow$ Critical Methodologies, 16(2) 99-110.

Steffen, W., Broadgate, W., Deutsch, L., Gaffney, O., \& Ludwig, C. (2015). The trajectory of the Anthropocene: The great acceleration. The Anthropocene Review, 2(1), 81-98.

Stengers, I. (2005). Introductory Notes on an Ecology of Practices. Cultural Studies Review. 11(1), 183-196.

Taguchi, H. L., \& St. Pierre, E. A. (2017). Using Concept as Method in Educational and Social Science Inquiry. Qualitative Inquiry, 23(9), 643-648.

Taylor, C.A., \& Hughes, C. (2016). Edu-crafting a cacophonous ecology: Posthumanist research practices for education. In C.A Taylor \& C. Hughes, Posthuman research practices in education (pp. 5-24). Hampshire, UK: Palgrave Macmillan.

Weinstein, J., \& Colebrook, C. (2016). Introduction: Critical life studies and the problems of 
inhuman rites and posthumous life. In J. Weinstein \& C. Colebrook (eds.), Posthumous Life: Theorising beyond the posthuman (pp. ix-xxvii). New York: Columbia University Press.

West-Eberhard, M. (2003). Developmental plasticity and evolution. Oxford, UK: Oxford University Press.

Whitehead, A.N. (1978). Process and reality. New York: The Free Press.

Wolfe, M. J. (2017). Post-Qualitative Filmic Research in Education: Utilizing a "Re/Active Documentary" Methodology. Qualitative Inquiry, 23(6), 427-437.

Zepke, S. (2005). The abstract machine: Art and ontology in Deleuze and Guattari. New York, NY: Routledge.

Author's Biography: David Rousell is Research Fellow in the Education and Social Research Institute at Manchester Metropolitan University, where he works in the Biosocial Research Lab (www.biosocialresarchlab.com). His $\mathrm{PhD}$, completed in 2017 at Southern Cross University, is entitled States and Territories: Re-imagining university learning environments for the Anthropocene. David's research combines his interest in speculative philosophy and social inquiry with his background as a visual artist and arts educator. His art has been exhibited in public exhibitions across North America, Europe, and Australasia, and he has taught visual art studio practice, art history, and art theory in secondary schools and in higher education. His recent research and artistic projects have focused on creating multi-sensory and immersive responses to the Anthropocene in collaboration with schools, universities, and community arts organisations. David's research has been published in international journals and books, including International Journal of Qualitative Studies in Education, International Journal of Education Through the Arts, Journal of Environmental Education, and ArtsResearch-Education: Connections and Directions (Springer). 
